\title{
Horizontal Restraints in Antitrust: Current Treatment and Future Needs
}

\author{
Harvey J. Goldschmid†
}

\section{I \\ Current Treatment}

I would first like to address what I consider the most fundamentaland least demanding - of the questions before us: Are the basic conceptual underpinnings supporting present policy on horizontal restraints in doubt? These underpinnings, of course, involve cartel and concentration theory. My answer is that they are robust, healthy, and indeed, should remain viable into the next century and beyond.

For those serious about antitrust, the debates in the horizontal restraint area should be at the margin. Clarion calls for fundamental change ought to fall on deaf ears. For example, whatever one's antitrust value scheme, I see no room for tolerance of hardcore horizontal price fixing or of production and territorial restraints. The same is true of certain conipetitor-excluding group boycotts. While I generally share the rich, multivalued framework for antitrust analysis that Professor Sullivan articulates so well, ${ }^{1}$ I do not see any reason - apart from relative quibbles about the instability of cartels over time-why antitrust analysis focused primarily on price and output should deviate from a broad condemnatory consensus of these hardcore practices.

In the past few decades, we have learned a good deal about industrial concentration. ${ }^{2}$ Although it is clear that prices above competitive levels do not autoniatically result from a concentrated market structure, there is still reason for significant concern about interdependent pricing and other parallel anticompetitive activities. Even most of the "Chicago School" recognize that concentrated markets, at a mininiuni, facilitate collusion. Thus, whether one approaches horizontal restraints from the University.

$\dagger$ Dwight Professor of Law, Columbia University. B.A. 1962, J.D. 1965, Columbia

1. See Sullivan, The Viability of the Current Law on Horizontal Restraints, 75 CALIF. L. REV. 835 (1987).

2. See, e.g., 3 P. Areeda \& D. TuRner, ANTitrust Law If 359-390 (1978); Industrial Concentration: The New Learning (H. Goldschmid, H. Mann \& J. Weston eds. 1974); F. Scherer, Industrial Market Structure and Economic Performance 151-266 (2d ed. 1980). 
left, right, or center, there is reason to monitor the conduct of companies in concentrated markets, to scrutinize horizontal venture agreements in concentrated markets, and in general, to take account of concentration theory in establishing horizontal merger policy.

Where, then, are there significant disputes? One issue, elegantly addressed by Professor Sullivan, relates to the proper role of per se rules in the horizontal restraints area. Professor Sullivan makes a heroic attempt to rehabilitate the turn-of-the-century antitrust approach of Justices Peckham and Harlan. He sees in their approach a "search[] for fixed and objective norms about what conduct violated the statute," 3 and juxtaposes their view against Chief Justice White's advocacy of a rule of reason inquiry that leads to "sweeping judicial discretion." 4 Professor Sullivan's rehabilitative attempt ultimately flounders though, because he tries to clothe indefensible literalism with theoretical justifications, such as concern about excessive judicial discretion. Instead, the basic case for per se rules must be made on a pragmatic, policy-oriented basis.

The Peckham-Harlan approach was simply too broad. Since it indiscriminately condemned all restraints of trade, it required the Justices to work too hard finding legal those restraints not "within the letter or spirit" of the Sherman $\mathrm{Act}^{5}$ and those restraints that only "indirectly and remotely" affected commerce. ${ }^{6}$ Chief Justice White's all-encompassing rule of reason, on the other hand, was simply unworkable, particularly when augmented by the broad inquiry mandated by Justice Brandeis in Chicago Board of Trade v. United States. ${ }^{7}$ The judicial process should not be opened to the broad inquiry that the rule of reason requires if, for example, hardcore price fixing is involved. ${ }^{8}$

My bottom line is that Professor Sullivan spends too much time with the wrong Justices. I see far more wisdom in exploring Chief Justice Stone's pragmatic, policy-oriented explanation for per se rules. In United States v. Trenton Potteries Co., ${ }^{9}$ Stone made the case for per se rules by emphasizing the danger of continued cartel power over price (even if an original price was "reasonable" when set), the need for clarity and certainty in the law, the value of making sensible use of courts' and litigants' time and resources, and similar factors. ${ }^{10}$

3. Sullivan, supra note 1 , at 837 .

4. Id.

5. United States v. Trans-Missouri Freight Ass'n, 166 U.S. 290, 329 (1897).

6. United States v. Joint Traffic Ass'n, 171 U.S. 505, 568 (1898).

7. 246 U.S. 231 (1918). Justice Brandeis advocated consideration of particular business facts such as the economic condition of the business, the nature and effect of the restraint, the history of the restraint, the evil sought to be remedied, and the intended result. Id. at 238.

8. See infra text accompanying notes 19-20.

9. 273 U.S. 392 (1927).

10. See id. at 396-98. 
With Professor Kauper, ${ }^{11}$ I find utility in the formulation articu-, lated in United States v. Addyston Pipe \& Steel Co. ${ }^{12}$ for determining when to use per se rules. Nevertheless, I see even greater advantage in the current Supreme Court's formulations in Continental T.V., Inc. $v$. GTE Sylvania, Inc. ${ }^{13}$ and other recent cases. ${ }^{14}$ These decisions provide more guidance and are more effective than the Addyston Pipe "nakedancillary" distinction because they specifically acknowledge the need for generalization and pragmatic balancing. As Justice Powell stated in GTE Sylvania: "Per se rules . . . require the Court to make broad generalizations about the social utility of particular commercial practices. The probability that anticompetitive consequences will result from a practice and the severity of these consequences must be balanced against its procompetitive consequences." 15 Although Justice Powell acknowledged that in some circumstances redeeming procompetitive consequences (such as efficiency gains) might have to be forfeited, he concluded that a "per se rule reflects the judgment that such cases are not sufficiently common or important to justify the time and expense necessary to identify them." 16 In other recent cases, the Supreme Court has suggested applying a per se rule when a "practice facially appears to be one that would always or almost always tend to restrict competition and decrease output."17

These formulations and discussions have contributed much to clearing up two of the largest areas of conceptual confusion regarding per se rules and horizontal restraints.

The first area of confusion was created by the Supreme Court's naive use of a "lack of redeeming virtue" test for determining when to apply a per se rule. ${ }^{18}$ This formulation suggested that any efficiency-no matter how small or how easily achieved by less anticompetitive alternativeswould prevent per se treatment. In theory, at least, one could hypothesize price fixing cartels that had some redeeming virtue because they better matched supply and demand or because they saved advertising and other distribution costs. The Supreme Court's new formulations make it clear that on balance, in price fixing cases (and in other sensitive areas), alleged efficiency gains cannot prevent per se treatment because they are

11. Kauper, The Sullivan Approach to Horizontal Restraints, 75 CALIF. L. Rev., 893 (1987).

12. 85 F. 271 (6th Cir. 1898), modified \& aff'd, 175 U.S. 211 (1899). Covenants in restraint of trade may be valid if "ancillary" to the main purpose of a contract, but are invalid if their "sole object" is to restrain competition. Id. at 282-83.

13. 433 U.S. 36 (1977).

14. E.g., Northwest Wholesale Stationers, Inc. v. Pacific Stationery \& Printing Co., 472 U.S. 284 (1985); Broadcast Music, Inc. v. Columbia Broadcasting Sys., 441 U.S. 1 (1979).

15. 433 U.S. at 50 n. 16.

16. Id.

17. Broadcast Music, 441 U.S. at 19-20; see also Northwest Wholesale, 472 U.S. at 293-98.

18. Northern Pac. Ry. Co. v. United States, 356 U.S. 1, 5 (1958). 
neither common nor important enough to justify the time and expense necessary to identify them. ${ }^{19}$ Moreover, the wrong parties-the cartel members and not the consuming public-would be the likely beneficiaries of any efficiency gains.

A second area of confusion was created in 1940 by the breadth of the "any combination which tampers with price" test, articulated by Justice Douglas in United States v. Socony-Vacuum Oil Co. ${ }^{20}$ This formulation, along with Douglas's "raising, depressing, fixing, pegging, or stabilizing" language, ${ }^{21}$ opened almost any horizontal arrangement to claims that it constituted per se price fixing. Socony-Vacuum was decided correctly on its facts (direct price stabilization was involved), but the virtually open-ended invitation to characterize most horizontal arrangements as per se "price tampering" has been wisely and firmly rejected in four recent Supreme Court decisions. ${ }^{22}$

II

Future NEEDS

Where do we go from here in the horizontal restraints area? What additional refinements or doctrinal changes are needed? I see four basic needs that figure to shape the future development of antitrust law and policy concerning horizontal restraints.

\section{The Need to Develop an Effective Analytical Framework for "Skimmed-Down" Rule of Reason Inquiries}

Professor Sullivan directs much of his Article to this issue, and it clearly warrants attention. As I have indicated, the Supreme Court has properly limited the definition of "per se price fixing." The Court is still searching, however, for a way of avoiding a full rule of reason inquiry in non-per se cases. Justice Stevens has led the way in developing a truncated-or, in terminology I prefer, "skimmed-down"-rule of reason inquiry. ${ }^{23}$ One difficulty, of course, as Justice Stevens's dissent in Broadcast Music, Inc. v. Columbia Broadcasting System ${ }^{24}$ demonstrates, is that judges may disagree about whether a given case warrants skimmed-down inquiry. What courts need is an analytical framework that will provide

19. See GTE Sylvania, 433 U.S. at 50 n.16.

20. 310 U.S. 150, 221 (1940).

21. Id. at 223 .

22. FTC v. Indiana Fed'n of Dentists, 106 S. Ct. 2009 (1986); NCAA v. Board of Regents, 468 U.S. 85 (1984); Broadcast Music, Inc. v. Columbia Broadcasting Sys., 441 U.S. 1 (1979); National Soc'y of Professional Eng'rs v. United States, 435 U.S. 679 (1978).

23. See NCAA, 468 U.S. at 98-104 (Stevens, J.); Professional Eng'rs, 435 U.S. at 687-92 (Stevens, J.); see also Indiana Fed'n of Dentists, 106 S. Ct. at 2017-21 (Justice White applying a version of "skimmed down" rule of reason analysis).

24. 441 U.S. at 25 (Stevens, J., dissenting). 
guidance as to when a skimmed-down inquiry is appropriate. Such a framework is particularly important for-and must be comprehensive to-the antitrust bar and district judges. Although work remains to be done, Professor Sullivan's emphasis on "less restrictive alternatives" and the analytical frameworks that he and Professor Kauper provide should prove quite helpful in the future.

\section{The Need to Learn How to Cope with More-and More Complex- Horizontal Restraint Cases}

For several reasons, I expect to see a significant increase in the number of horizontal restraint cases. First, the federal and state deregulation efforts that have been ongoing for roughly two decades ${ }^{25}$ will continue to create considerable work for the courts. Companies that until recently were "warmly regulated" do not always like the "competitive cold." I suspect that problems created by companies seeking to come out of the competitive cold through improper means are only now beginning to surface.

Second, the government's present overly permissive horizontal merger policy may well lead to more frequent and more effective anticompetitive exchanges of information and to the more frequent employment of so-called "facilitating practices." Furthermore, greater market concentration will make the detection of conspiracies more difficult.

Third, while the easy entry of foreign competitors clearly produces substantial procompetitive benefits, many of these foreign firms have developed their business practices under very different legal and economic conditions than those existing in the U.S. These firms may well provide serious antitrust enforcement officials with a good deal of work in the future.

I also expect to see more complex horizontal restraint cases. In Broadcast Music, the Supreme Court rejected "easy [per se] labels," 26 and in FTC v. Indiana Federation of Dentists, ${ }^{27}$ the Court disavowed formalistic per se "pigeonholes."28 In these two cases, and again in NCAA v. Board of Regents ${ }^{29}$ and Northwest Wholesale Stationers v. Pacific Sta-

25. Federal deregulatory efforts have, for example, involved the airlines, financial markets, and telecommunications. State efforts have been the result of both direct legislative action and judicial limitation on the state action exemption. See, e.g., Parker v. Brown, 317 U.S. 341 (1943), and cases collected in M. Handler, H. Blake, R. Pitofsky \& H. Goldschmid, Cases and Materials ON Trade Regulation $1071-1103$ (2d ed. 1983) \& 168-207 (Supp. 1987).

26. 441 U.S. at 8.

27. 106 S. Ct. 2009 (1986).

28. Id. at 2018.

29. 468 U.S. 85 (1984). 
tionery \& Printing Co. ${ }^{30}$ the Court properly recognized that horizontal arrangements (often joint ventures of one type or another) with plausible efficiency-enhancing rationales require serious analysis and not literalistic extensions of per se rules. The fact that a rule of reason analysis led to findings of unreasonable restraint in two of the four cases (NCAA and Indiana Federation of Dentists) constitutes a warning that the rule of reason may no longer be predominantly a defendant's rule. Regardless of which side this rule favors, more serious rule of reason analysis undoubtedly will increase the complexity of antitrust litigation in the federal courts.

The growing service sector and the need to deal with the various professions will also add complexity. Similarly, although the Supreme Court was clearly correct in concluding recently that "the sweeping language of $\S 1$ of the Sherman Act applies to nonprofit entities," 31 the coverage of this so-called "third sector" of the economy may add new wrinkles. Finally, issues related to the international reach of our antitrust laws in a shrinking world present another cause of increased complexity.

\section{The Need to Develop an Effective Analytical Framework Leading to Early Findings of Reasonableness in Appropriate Cases}

Considerable intellectual rewards are available for those attempting to develop an analytical framework that would permit early findings of reasonableness in appropriate cases. Such a framework is the conceptual underpinning of the various recent attempts to devise quick looks, screens, and filters. At this time, at least in my view, a few very interesting attempts in this direction have been made, but none has been ultimately satisfying. In any event, even without an adequate general framework, the recent Georgetown Study shows that federal judges increasingly are using summary disposition motions to weed out cases they perceive to be meritless. ${ }^{32}$

\section{The Need to Tinker Fruitfully with the Procedural and Remedial Scheme for Horizontal Restraint Cases}

Given the important general deterrence values involved, the Antitrust Division's current emphasis on imprisonment for hardcore horizontal restraint offenses is entirely laudatory. On the other hand, at the margin, I would support some change in the treble damage remedy. I am particularly concerned about the vagueness and malleability of various

30. 105 S. Ct. 2613 (1985).

31. NCAA, 468 U.S. at 100 n.22.

32. See Calkins, Summary Judgment, Motions to Dismiss, and Other Examples of Equilibrating Tendencies in the Antitrust System, 74 GEO. L.J. 1065, 1131-32 (1986). 
antitrust rules (such as those related to joint ventures in the horizontal restraint area) and the danger of potentially disastrous liability for relatively innocent defendants. My ameliorating approach is to eliminate mandatory trebling when a judge in a non-per se case finds that a defendant reasonably believed that a given act, venture, or transaction did not violate the antitrust laws. ${ }^{33}$

I have a number of other proposals in mind for changing various procedural and remedial aspects of the antitrust system. For present purposes, however, I simply would like to suggest that future creative tinkering should be able to reduce some of the perverse incentives that now distort and extend antitrust litigation.

33. My view on this issue is discussed at greater length in Goldschmid. Comment on the Policy Implications of the Gcorgetown Study (forthcoming in THE GEORGETOWN STUdY (S. Salop \& L. White eds. 1987)). 
